
DC) IN WISTAR MALE WHITE RAT

\title{
AKTIVITAS ANALGESIK EKSTRAK ETANOL DAUN SOYOGIK (Saurauia bracteosa DC) PADA TIKUS PUTIH JANTAN GALUR WISTAR
}

\author{
Dina Imorina Legoh ${ }^{1}$, Max R.J. Runtuwene'), Paulina V.Y. Yamlean') \\ ${ }^{1)}$ Program Studi Farmasi FMIPA UNSRAT Manado, 95115 \\ *imorinalegoh@gmail.com
}

\begin{abstract}
Soyogik leaves (Saurauia bracteosa DC) are plants that have flavonoid compounds that act as analgesics. This study aims to test the analgesic activity of soyogic leaf extract on male white rats Wistar strain using the thermic pain induction method. This research method is laboratory experimental, using male white rats (Rattus novergicus). The results obtained from the number of responses of mice between before and after giving the test solution. The treatment was initiated by thermal induction of pain in rats. Furthermore, the rat response was calculated, then given negative control (CMC), positive control (paracetamol), and soyogic leaf extract with a dose of $0.375 \mathrm{~g} / \mathrm{KgBB}, 0.75 \mathrm{~g} / \mathrm{KgBB}$ and $1.5 \mathrm{~g} / \mathrm{KgBB}$. The response of the mice after being given the treatment was seen from the 30th, 60th, 90th, and 120th minutes. Data were analyzed using the SPSS program, the real differences between the treatments were tested by one way ANOVA. The results showed that soyogic leaf extract with a dose of $0.375 \mathrm{~g} / \mathrm{KgBB}$, a dose of $0.75 \mathrm{~g} / \mathrm{KgBB}$ and a dose of $1.5 \mathrm{~g} / \mathrm{KgBB}$ have analgesic activity.
\end{abstract}

Keywords: analgesics, Saurauia bracteosa DC, Rattus norvegicus

\begin{abstract}
ABSTRAK
Daun soyogik (Saurauia bracteosa DC) merupakan tanaman yang memiliki senyawa flavonoid yang berperan sebagai analgesik. Penelitian ini bertujuan untuk menguji aktivitas analgesik dari ekstrak daun soyogik pada tikus putih jantan galur wistar dengan metode induksi nyeri cara termik. Metode penelitian ini adalah eksperimental laboratorium, menggunakan tikus putih jantan (Rattus novergicus). Hasil penelitian diperoleh dari jumlah respon tikus antara sebelum dan sesudah pemberian larutan uji. Perlakuan diawali dengan induksi nyeri cara termik pada tikus. Selanjutnya dihitung jumlah respon tikus, kemudian diberikan kontrol negatif (CMC), kontrol positif (paracetamol), dan ekstrak daun soyogik dosis $0,375 \mathrm{~g} / \mathrm{KgBB}, 0,75 \mathrm{~g} / \mathrm{KgBB}$ dan $1,5 \mathrm{~g} / \mathrm{KgBB}$. Respon tikus setelah diberikan perlakuan dilihat mulai dari menit ke 30, 60, 90, dan 120. Data dianalisis menggunakan program SPSS, beda nyata antar perlakuan diuji dengan one way ANOVA. Hasil yang didapat menunukkan ekstrak daun soyogik dosis $0,375 \mathrm{~g} / \mathrm{KgBB}$, dosis $0,75 \mathrm{~g} / \mathrm{KgBB}$ dan dosis $1,5 \mathrm{~g} / \mathrm{KgBB}$ memiliki aktivitas analgesik.
\end{abstract}

Kata Kunci: analgesik, Saurauia bracteosa DC, Rattus norvegicus. 


\section{PENDAHULUAN}

Nyeri adalah pengalaman sensoris dan emosional yang tidak menyenangkan akibat dari kerusakan jaringan yang aktual atau potensial. Nyeri dapat disebabkan karena adanya kerusakan jaringan dalam tubuh sebagai akibat dari adanya cedera, kecelakaan, maupun tindakan medis seperti operasi (Ratnasari, 2013).

Analgetika adalah zat yang bisa mengurangi rasa nyeri tanpa mengurangi kesadaran (Tjay dan Rahardja, 2015). Analgesik yang sering digunakan masyarakat adalah yang memiliki kandungan parasetamol, ibuprofen, asam mefenamat, dan lain-lain, namun obat-obatan kimia tersebut memilik efek samping yang kurang baik bagi tubuh kita apabila di gunakan dalam jangka waktu panjang (Sardjono dkk, 1995).

Salah satu jenis tanaman obat tradisional yang daunnya dipercaya secara empiris oleh masyarakat Tombatu, Sulawesi Utara adalah daun soyogik (Muaja, dkk 2013). Berdasarkan hasil penelitian skrining fitokimia dan antioksidan yang telah dilakukan oleh Kadji (2013) pada daun soyogik terdapat senyawa fenolik, steroid, flavonoid, dan saponin. Masing-masing senyawa memiliki manfaat dalam pengobatan penyakit tertentu dan salah satu senyawa yang dapat mengobati nyeri yaitu flavonoid. Flavonoid adalah senyawa yang dapat melindungi membran lipid dari kerusakan dan mekanisme kerjanya menghambat enzim cyclooxygenase I yang merupakan jalur pertama sintesis mediator nyeri seperti prostaglandin (Mikaili, P . 2012). Sampai saat ini belum ada pengujian ilmiah tentang ekstrak etanol daun soyogik sebagai obat analgesik. Berdasarkan hal diatas maka penulis ingin melakukan penelitian uji efek analgesik ekstrak etanol daun soyogik (Sauraia bracteosa DC) pada tikus putih jantan galur wistar (Rattus norvegicus).

\section{METODOLOGI PENELITIAN}

\section{Alat dan Bahan}

Alat yang digunakan dalam penelitian ini yaitu masker, sarung tangan, jas lab, kamera, oven, cawan petri, gelas ukur, erlenmeyer, blender, timbangan analitik, timbangan hewan, lumpang, sudip, batang pengaduk, kertas saring, sonde oral, disposable syringe (1cc dan $3 \mathrm{cc}$ ), waterbath, termometer, kandang hewan uji, tempat makan dan minum hewan uji.

Bahan yang digunakan yaitu daun soyogik, etanol $70 \%$, akuades, CMC $1 \%$, parasetamol, tikus putih jantan galur wistar, dan pakan tikus.

\section{Pengambilan Sampel}

Sampel daun soyogik diambil di daerah sekitar gunung Soputan, Desa Tombatu, Sulawesi Utara. Bagian sampel yang digunakan adalah daun. Sampel yang diambil dibersihkan dari kotoran dan serangga. Sampel daun soyogik yang telah dibersihkan, disortasi dengan cara mengamati keutuhan bentuk sampel daun yang akan diolah menjadi simplisia.

\section{Penyiapan Serbuk}

Sampel daun soyogik dikeringkan dengan cara diangin-anginkan selama \pm 1 minggu. Setelah itu dimasukkan ke dalam oven pada suhu $40^{\circ} \mathrm{C}$ hingga ketika diremas sampel daun menjadi hancur sebagai indikator kadar air dari sampel telah berkurang. Sampel yang telah dikeringkan kemudian dibuat serbuk dengan menggunakan blender khusus bahan kering.

\section{Penyiapan Hewan Uji}

Tikus putih jantan sebanyak 15 ekor di bagi menjadi 5 kelompok. Kelompok A (kontrol negatif) 3 tikus diberi suspensi CMC 1\%, kelompok B (kontrol positif) 3 tikus diberi Paracetamol 9 mg, Kelompok C (ekstrak daun soyogik dosis 1) 3 tikus diberi ekstrak etanol daun soyogik dosis $0,375 \mathrm{~g} / 200 \mathrm{~g} \quad \mathrm{BB}$, Kelompok D (ekstrak daun soyogik dosis 2) 3 tikus diberikan ekstrak etanol daun soyogik dosis $0,75 \mathrm{~g} / 200 \mathrm{~g} \mathrm{BB}$, dan kelompok D (ekstrak daun soyogik dosis 3$) 3$ tikus diberikan ekstrak etanol daun soyogik dosis $1,5 \mathrm{~g} / 200 \mathrm{~g} \mathrm{BB}$.

\section{Ekstraksi}

Ekstraksi dilakukan dengan metode maserasi menggunakan pelarut etanol $70 \%$ selama 5 x 24 jam. Simplisia sebanyak 250 gr dilarutkan dalam $2000 \mathrm{~mL}$ etanol $70 \%$ sambil sesekali diaduk dengan perbandingan 1:8. Setelah 5 hari, disaring menggunakan kertas saring dan didapatkan filtrat dan residu. Proses ekstraksi dilanjutkan dengan remaserasi residu dengan ditambahkan pelarut $1000 \mathrm{~mL}$ etanol $70 \%$ dengan perbandingan 1:4. Ekstrak cair yang diperoleh kemudian diuapkan dan dipekatkan menggunakan oven dengan suhu $40^{\circ} \mathrm{C}$ sampai diperoleh ekstrak etanol daun soyogik.

\section{Pembuatan Suspensi CMC 1\%}

Sebanyak 1 gr CMC dilarutkan dalam akuades yang telah dipanaskan sebanyak $10 \mathrm{~mL}$ aduk sampai mengembang dan homogen. 
Volume 10 Nomor 2 Mei 2021

Setelah itu ditambahkan akuades sedikit demi sedikit hingga volume $100 \mathrm{~mL}$.

\section{Penentuan Dosis Ekstrak Etanol Daun Soyogik dan Paracetamol}

a. Ekstrak etanol daun soyogik Volume cairan maksimal yang dapat diberikan per oral pada tikus adalah $5 \mathrm{~mL} / 200 \mathrm{~g}$ (Ngatidjan, 1991). Takaran konversi dosis untuk manusia dengan berat badan (BB) $70 \mathrm{~kg}$ pada tikus dengan BB $200 \mathrm{~g}$ yaitu 0,018. Ratarata berat badan dewasa orang Indonesia $50 \mathrm{~kg}$. Dosis daun soyogik yang digunakan adalah dosis yang biasa dipakai di masyarakat yaitu 10 helai daun Soyogik, jika dikonversi menjadi \pm 30 gram.

Maka dosis untuk tikus

$=\left(\left(\frac{70}{50} \times 30\right) \times 0,018\right) g$

$=(42 \times 0,018) \mathrm{g}$

$=0,75 \mathrm{~g} / 200 \mathrm{~g} \mathrm{BB}$

Dalam pengujian digunakan dosis ekstrak daun Soyogik yang bertingkat :

Kelompok uji I : Dosis $1=0,5 \times 0,75 \mathrm{~g}$

$$
=0,375 \mathrm{~g} / 200 \mathrm{~g} \mathrm{BB}
$$

Kelompok uji II : Dosis $2=1 \times 0,75 \mathrm{~g}$

$$
=0,75 \mathrm{~g} / 200 \mathrm{~g} \mathrm{BB}
$$

Kelompok uji III : Dosis $3=2 \times 0,75 \mathrm{~g}$

$$
=1,5 \mathrm{~g} / 200 \mathrm{~g} \mathrm{BB}
$$

Ekstrak daun Soyogik pada masingmasing dosis, dilarutkan dalam suspensi CMC $1 \%$ dan diberikan secara oral sesuai dengan berat badan masing-masing tikus. Pemberian ekstrak daun soyogik pada tikus dilakukan dengan cara dikeluarkan tikus dari kandang. Tikus diangkat pada pangkal ekor, diletakkan diatas permukaan kawat. Tangan kiri diletakkan dipunggung tikus ke arah kepala. Selipkan kepala diantara jari telunjuk dan dari tengah, sedangkan ibu jari, jari manis dan kelingking diselipkan disekitar perut sehingga kaki depan kiri dan kanan terselip diantara jari. Langkah berikut pencengkokkan, dimulai dari penyodotan ekstrak daun soyogik menggunakan sonde oral. Mulut tikus dibuka selanjutnya sonde oral dimasukkan secara perlahan dan ekstrak daun soyogik disemprotkan.

\section{b. Kontrol Positif}

Sebagai kontrol positif digunakan obat analgesik paracetamol. Dosis paracetamol untuk manusia dewasa ialah $500 \mathrm{mg}$, maka dosis untuk tikus ialah $500 \mathrm{mg} \times 0,018=9$ $\mathrm{mg} / 200 \mathrm{~g}$ BB. 0,018 merupakan konversi dosis manusia ke tikus

\section{Pengujian Aktivitas Analgesik}

Langkah-langkah pengujian efek analgetik pada hewan uji ialah sebagai berikut:

a. Beaker glass dimasukkan ke dalam waterbath yang berisi air, kemudian waterbath dipanaskan hingga suhu $55^{\circ} \mathrm{C}$. Setelah suhu mencapai $55^{\circ} \mathrm{C}$, tikus dimasukkan ke dalam beaker glass tersebut.

b. Setelah tikus ada di dalam beaker glass maka responnya diamati, yaitu berupa gerakan menjilat kaki dan atau melompat. Pengamatan dilakukan selama 1 menit.

c. Masing-masing kelompok tikus diberikan larutan ekstrak etanol daun soyogik, larutan kontrol positif CMC 1\% dan akuades sebagai kontrol negatif. Tikus lalu diistirahatkan untuk diamati kembali pada menit ke-30.

d. Pengamatan dilakukan hingga menit ke120, dengan interval waktu 30 menit untuk setiap pengamatan.

e. Pengamatan dilakukan sebanyak 5 kali, yaitu:

1. Sebelum pemberian zat uji

2. Menit ke-30 setelah pemberian zat uji

3. Menit ke-60 setelah pemberian zat uji

4. Menit ke-90 setelah pemberian zat uji

5. Menit ke-120 setelah pemberian zat uji

\section{Analisis Data}

Data penurunan kadar glukosa darah yang diperoleh selanjutnya dianalisis secara statistika menggunakan one way ANOVA (Analysis of Varians).

\section{HASIL DAN PEMBAHASAN \\ Pembuatan Ekstrak}

Ekstrak cair daun soyogik (Saurauia bracteosa DC) yang dihasilkan oleh proses ekstraksi maserasi dengan menggunakan pelarut etanol $70 \%$ adalah $800 \mathrm{~mL}$. Hasil proses maserasi, disimpan kemudian debrisnya dilanjutkan remaserasi yang menghasilkan 940 $\mathrm{mL}$ ekstrak cair daun soyogik. Ekstrak cair hasil maserasi dan remaserasi yang digabungkan dan dikentalkan menghasilkan 23,57 gram ekstrak kental daun soyogik (Saurauia bracteosa DC).

\section{Pengukuran Penurunan Respon Hewan Uji}

Hewan uji yang digunakan dalam penelitian ini yaitu tikus putih jantan galur 
PHARMACON- PROGRAM STUDI FARMASI, FMIPA, UNIVERSITAS SAM RATULANGI,

Volume 10 Nomor 2 Mei 2021

wistar (Rattus norvegicus) dengan berat badan 140-180 gram karena biologis tikus jantan lebih stabil dibandingkan dengan tikus betina. Hewan uji yang diinduksikan nyeri dengan cara termik memberikan respon berupa menjilat dan atau melompat. Reseptor panas memiliki respon terhadap suhu $30-45^{\circ} \mathrm{C}$. Suhu diatas $45^{\circ} \mathrm{C}$ mulai terjadi kerusakan jaringan akibat panas dan sensasinya berubah menjadi nyeri. Jadi rasa nyeri yang disebabkan oleh panas sangat erat hubungannya dengan kemampuan panas untuk merusak jaringan (Guyton, 1994). Pada penelitian ini kelompok kontrol negatif, tikus 1 menghasikan respon sebanyak 14 gerakan, tikus 2 menghasilkan 12 gerakan, dan tikus 3 menghasilkan 12 gerakan. Sedangkan untuk kontrol positif, tikus 1 memberikan respon berupa 20 gerakan, tikus 2 memberikan respon 17 gerakan, tikus 3 memberikan respon 7 gerakan. Untuk hasil respon tikus kelompok perlakuan dosis 1 yaitu tikus 1 memberikan respon sebanyak 19 gerakan, tikus 2 menghasilkan 11 gerakan dan tikus ke-3 menghasilkan 10 gerakan. Perlakuan dosis 2 tikus 1 menghasilkan 16 gerakan, tikus 2 dan 3 memberikan respon sebanyak 18 gerakan. Untuk hasil penurunan kelompok perlakuan dosis 3 yaitu pada tikus 1 menghasilkan respon sebanyak 21 gerakan, tikus 2 sebanyak 22 gerakan dan tikus 3 sebanyak 14 gerakan.

Hasil pengamatan penurunan rata-rata respon tikus dapat dilihat pada Tabel 3.

Tabel 3. Hasil Rata-Rata Penurunan Respon Tikus

\begin{tabular}{|c|c|c|c|c|c|}
\hline \multirow[b]{2}{*}{$\begin{array}{l}\text { Kelompok } \\
\text { Perlakuan }\end{array}$} & \multirow[b]{2}{*}{$\begin{array}{c}\text { Respon Tikus } \\
\text { Sebelum } \\
\text { Perlakuan }\end{array}$} & \multicolumn{4}{|c|}{$\begin{array}{c}\text { Waktu } \\
\text { Respon Tikus Setelah Perlakuan }\end{array}$} \\
\hline & & $\begin{array}{c}\text { Menit ke- } \\
30\end{array}$ & $\begin{array}{l}\text { Menit ke- } \\
\quad 60\end{array}$ & $\begin{array}{l}\text { Menit ke- } \\
\quad 90\end{array}$ & $\begin{array}{c}\text { Menit ke- } \\
120\end{array}$ \\
\hline K (-) & 12,6 & 18,6 & 19,6 & 10,6 & 14,3 \\
\hline $\mathbf{K}(+)$ & 14,6 & 14,3 & 3,3 & 1 & 0,6 \\
\hline P1 & 13,3 & 12,3 & 11,6 & 4,3 & 1,6 \\
\hline P2 & 17,3 & 16,3 & 10 & 3,3 & 1,3 \\
\hline P3 & 19 & 15,3 & 10,3 & 1,3 & 0,6 \\
\hline
\end{tabular}

Keterangan :

$\mathrm{K}(+) \quad$ : Kelompok kontrol negatif

K (-) : Kelompok kontrol positif

P1 : Kelompok perlakuan ekstrak etanol daun soyogik dosis $0,375 \mathrm{~g} / 200 \mathrm{~g} \mathrm{BB}$

P2 : Kelompok perlakuan ekstrak etanol daun soyogik dosis $0,75 \mathrm{~g} / 200 \mathrm{~g} \mathrm{BB}$

P3 : Kelompok perlakuan ekstrak etanol daun soyogik dosis 1,5 g/200 g BB

Dapat dilihat grafik perbedaan penurunan respon hewan uji sebelum dan sesudah diberikan perlakuan pada gambar 3 .

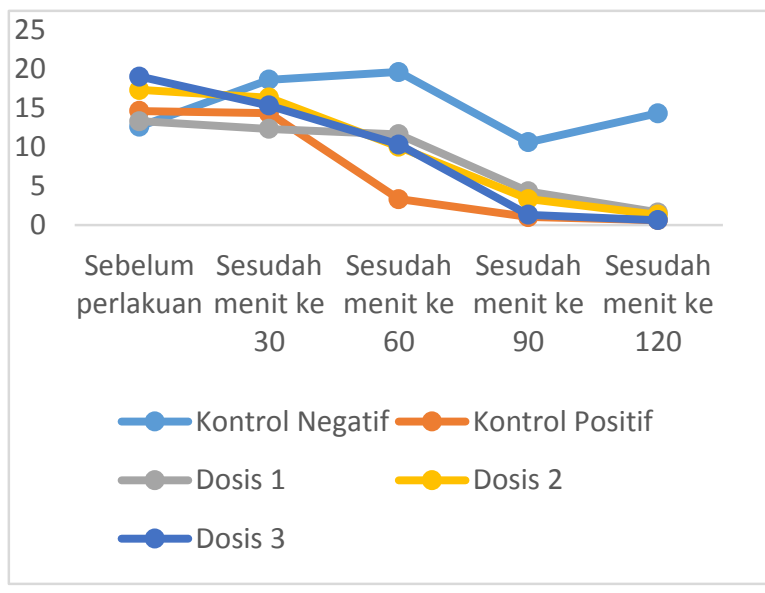

Gambar 3. Grafik rata-rata penurunan respon tikus

Berdasarkan data hasil penelitian, pada menit ke 30 setelah penginduksian nyeri selama 1 menit dan waktu istirahat, respon tikus mengalami penurunan respon kecuali pada kelompok kontrol negatif yang hanya diberikan CMC. Kelompok kontrol negatif mengalami respon yang bervariasi, namun dibandingkan dengan kontrol positif dan perlakuan, hanya kontrol negatif yang sering mengalami kanaikan respon. Hal ini dikarenakan CMC 
tidak mengandung zat aktif yang dapat mengurangi rasa nyeri. Pada kelompok kontrol positif yang diberikan obat parasetamol, menunjukkan penurunan respon rata-rata hewan uji terhadap rangsangan nyeri. Aktivitas analgesik dari kontrol positif parasetamol terus terlihat dari menit 30 sampai menit ke 120 . Hal ini dikarenakan obat analgesik parasetamol bekerja dalam menghambat siklooksigenase. Parasetamol menghambat siklooksigenase sehingga konversi asam arakhidonat menjadi prostaglandin terganggu (Gunawan, 2009). Parasetamol telah terbukti efek analgetik dan antipiretiknya, begitu juga dengan keamanannya.

Kelompok perlakuan ekstrak daun soyogik dosis 1 yaitu $0,375 \mathrm{~g}$, dosis $20,75 \mathrm{~g}$ dan dosis 3 1,5 g, hasil menunjukkan adanya penurunan respon tikus pada menit ke 30, 60, 90 sampai pada menit ke 120 . Penurunan yang terus terjadi artinya bahwa ekstrak daun soyogik ini memiliki efek analgetik pada tikus. Aktivitas analgetik esktrak etanol daun soyogik dikarenakan senyawa flavonoid. Flavonoid berperan sebagai analgetik yang mekanisme kerjanya menghambat kerja enzim siklooksigenase (Suryanto, 2012).

\section{KESIMPULAN}

Ekstrak etanol daun soyogik (Saurauia bracteosa $\mathrm{DC}$ ) dengan dosis $0,375 \mathrm{~g} / \mathrm{Kg} \mathrm{BB}$, dosis $0,75 \mathrm{~g} / \mathrm{Kg} \mathrm{BB}$, dan dosis $1,5 \mathrm{~g} / \mathrm{Kg} \mathrm{BB}$ memiliki efek analgesik pada tikus putih jantan galur wistar (Rattus norvegicus).

\section{SARAN}

Perlu dilakukan penelitian lebih lanjut mengenai dosis minimum, maksimum dan dosis toksik ekstrak daun soyogik (Saurauia bracteosa DC) untuk ditemukan dosis yang optimal.

\section{DAFTAR PUSTAKA}

Gunawan, S.G., Setiabudy, R., Nafrialdi, Elysabeth, editor. 2008. Farmakologi dan Terapi Edisi 5. Departemen Farmakologi dan Teraupetik Fakultas Kedokteran Universitas Indonesia, Jakarta.

Guyton, A. C. 1994. Buku Ajar Fisiologi Kedokteran. Terjemahan K. A. Tengadi. EGC, Jakarta.

Kadji, H. M. 2013. Uji Fitokimia dan Aktivitas Antioksidan dan Ekstrak Etanol Daun Soyogik (Sauraia bracteosa DC).
[Skripsi]. Fakultas Matematika dan Ilmu Pengtahuan Alam Universitas Sam Ratulangi, Manado.

Muaja, A. D., Koleangan, H. S. J., \& Runtuwene, M. R. J. 2013. Uji Toksisitas dengan Metode BSLT dan Analisis Kandungan Fitokimia Ekstrak Daun Soyogik (Saurauia bracteosa DC) dengan Metode Soxhletasi. Jurnal FMIPA Unsrat Online. 2(2).

Mikaili, P., Sharifi, M., Sarahroodi, S., \& Shayegh, J. 2012. Pharmacological review of medicinal trees spontaneous in Iran: A historical and modern study. Advances in Environmental Biology, 6(1).

Ratnasari. 2013. Pengaruh Pemberian Guided Imagery Terhadap Nyeri Pada Pasien Post Operasi Fraktur Di RSUD Panembahan Senopati Bantul 4. Salemba Medika, Jakarta.

Suryanto, E. 2012. Fitokimia Antioksida. PMN, Surabaya.

Sardjono O. S., Hedi R. D. 1995. Farmakologi dan Terapi. Edisi 4. Gaya Baru, Jakarta.

Tjay, T. H. dan Rahardja, K. 2015. Obat-Obat Penting Khasiat, Penggunaan dan Efek Efek Sampingnya. PT Elex Media Komputindo, Jakarta. 